\title{
EVALUATION OF AGARWOOD (AQUILARIA MALACCENIS) FROM BINTAN ISLAND BASED ON INDONESIAN STANDARD: PREDICTING ITS QUALITY USING NEAR-INFRARED SPECTROSGOPY
}

\author{
Karlinasari L ${ }^{1, *}$, Pratama NA ${ }^{1}$, Noviyanti ${ }^{1}$, Purwanto $\mathrm{YA}^{2} \&$ Turjaman $\mathbf{M}^{3}$ \\ ${ }^{1}$ Department of Forest Product, Faculty of Forestry and Environment, IPB University, Kampus IPB Darmaga Bogor 16680 \\ ${ }^{2}$ Department of Mechanical Engineering and Bio-system, Faculty of Agricultural Technology, IPB University, Kampus IPB \\ Darmaga Bogor 16680 \\ ${ }^{3}$ Forestry Research, Development, and Innovation Agency, Minsitry of Environment and Forestry, Republic of Indonesia, \\ Jln. Gunung Batu, Bogor 16118 \\ *karlinasari@apps.ipb.ac.id
}

Submitted August 2020; accepted December 2020

\begin{abstract}
The agarwood grading system in Indonesia comprises physical properties, such as colour, weight and aroma. Agarwood resin content can be a simple guide for grading agarwood quality. Thus, this research aimed to evaluate the quality of agarwood (Aquilaria malaccensis) from Bintan Island based on Indonesian standard, and to determine its resin content, using near-infrared (NIR) spectroscopy (NIRS), as a predicting model for agarwood quality. The samples were obtained from community plantation forest in Bintan island which were inoculated by Fusarium solani. Agarwood chips were graded by its colour, weight and aroma, and were converted into powder samples for colour testing and NIRS acquisition, as well as laboratory testing for resin content determination. Results, according to SNI 7631-2011, showed the agarwood quality of gubal gaharu (agar) and kemendangan (dhum) where the colour of gubal gaharu was darker than kemendangan, showing that gubal gaharu had higher resin content $(24.74 \%)$ than kemendangan $(12.22 \%)$. The NIR spectroscopy analysis showed that the partial least square regression (PLSR) model could be used to predict the resin content with passable accuracy.
\end{abstract}

Keywords: Resin content, Fusarium solani, gaharu, kemendangan, PLSR model

\section{INTRODUCTION}

Agarwood, also known as gaharu, aloeswood, eaglewood, karas or oudh, is obtained from an infected tree as a respond to wounding, fungal attack or non-pathological processes which lead to changes in physiology and chemistry of wood. The tree releases resin formation as a response to internal injury or infections, mainly in the tree stems. The most important tree species that produce agarwood is Aquilaria malaccensis. Other species come from the genus Aquilaria and Gyrinops (Thymelaceae). The incenses and perfumes that are produced from agarwood have been valued for centuries and used by many cultures for spiritual, opulent and aphrodisiac purposes (López-Sampson \& Page 2018). In Indonesia, agarwood is one of the non-timber forest product commodities that has high economic value. However, an international standard for determining the quality of agarwood is yet to be provided, as it is difficult to determine the quality and grading of a bio-product (Mohamed \& Lee 2016). Various parameters and preferences are used in different countries to determine agarwood quality. Grading is important for defining product quality in the market, which influences price determination as well as trade transparency (Giovannucci \& Reardon 2000). According to SNI7631-2011, the grading system in Indonesia includes physical properties, such as colour, weight and flavor (BSN 2011). These parameters are subjected to the ability and skills of the grader. Therefore, a more objective parameter, conducted by laboratory testing, is needed. Some researchers have explained how to simply determine the quality of agarwood by its resin content (Azah et al. 2013). The resin content is an extractive compound of the agarwood that 
indicates distinct fragrance, colour and resistance against organisms.

Determining the quality of agarwood by its chemical compounds is time-consuming and expensive. A more efficient alternative method is infrared spectroscopy (NIRS), which is commonly used for chemometrics research. Chemometrics is a chemical discipline that uses mathematical, statistical and other methods to provide maximum relevant chemical information by analysing chemical data. The NIRS is a technology that can rapidly analyse data without emission, with a simple sample preparation without chemicals (Osborne et al. 1993).

The NIRS has been used in wood researches to determine chemical compounds, as well as physical and mechanical properties, and were successful in predicting the properties of various wood ( $\mathrm{He} \& \mathrm{Hu} 2013$, Jiang et al. 2013, Karlinasari et al. 2014, 2021). A review on the application of NIRS in wood science and technology was published by Tsuchikawa \& Kobori (2015). Popescu et al. (2018), Traoré et al. (2018) and Ito et al. (2019) conducted research to distinguish infrared (IR) bands in wood species, both in original and wood modification. Research by Adi et al. (2020) has reported that NIRS was successfully used to separate normal and infected agarwood using multivariate analysis of partial least square-discriminant analysis (PLSDA). The current study aimed to determine and evaluate the quality of Agarwood according to Indonesian standard (SNI 7631-201), as well as to predict the resin content of agarwood using NIRS.

\section{MATERIALS AND METHODS}

\section{Sample preparation}

The agarwood was obtained from three 11-yearold A. malaccensis trees from the community plantation forest in Bintan island, Bangka Belitung islands $\left(1^{\circ} 01^{\prime} \mathrm{N} 104^{\circ} 29^{\prime} \mathrm{E}\right)$ which were inoculated by Fusarium solani (isolate code: FORDA CC00500) about 30 months before harvest. The $F$. solani is a fungus, dominantly associated with Aquilaria spp. (Faizal et al. 2017). The agarwood obtained was carved into chips and separated from normal wood (Figure 1). The chips were then graded by local experts to categorise the quality as stipulated by SNI 7631-2011 (Table 1). The evaluation included a burning test to obtain the fragrance of agarwood. The chips were then grouped based on quality and milled into meal using a Willey mill, and sieved to meal size 40-60 mesh. All samples were kept sealed at air-dry moisture content. Laboratory testing was conducted to determine agarwood colour and resin content.

\section{Agarwood colour determination}

Determining the colour of agarwood was done using a chromameter (CR-310). The powder samples $(50 \mathrm{~g})$ were tested and the colour values

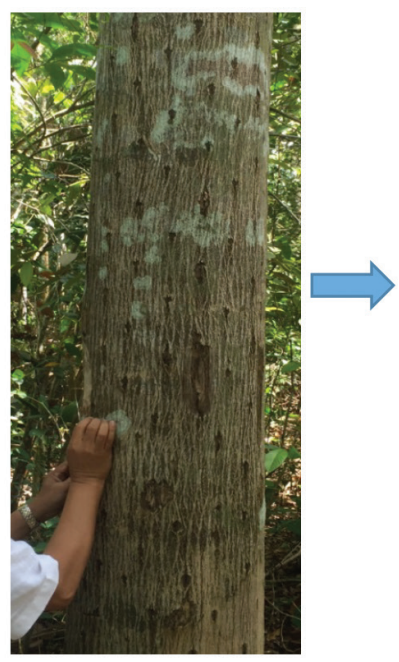

(a)

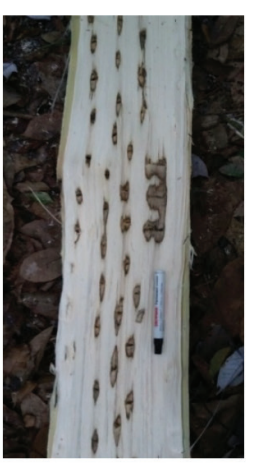

(b

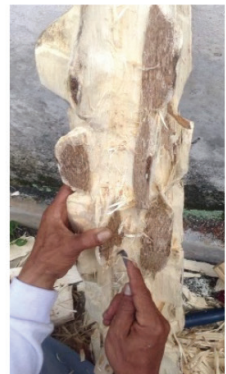

(c)

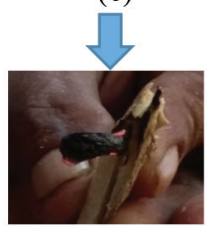

(d)

Figure 1 Sample of agarwood, inoculated agarwood tree (a), log containing agarwood (b), agarwood carving (c), burning test of agarwood (d) 
determined using the International Commission on Illumination $\mathrm{L}^{*} \mathrm{a} * \mathrm{~b} *$ (CIELAB) system; lightness $\left(\mathrm{L}^{*}\right)$, redness $\left(\mathrm{a}^{*}\right)$, yellowness $\left(\mathrm{b}^{*}\right)$, chroma $\left(\mathrm{C}^{*}\right)$ and hue value $\left({ }^{\circ} \mathrm{H}\right)$. The ${ }^{\circ} \mathrm{H}$ was used to categorise the colour according to colour criteria by Winarno (1992) (Table 2).

\section{Resin content determination}

The resin content of agarwood was determined based on WHO (1998). Approximately $4 \mathrm{~g}$ of agarwood powder was placed in a glass bottle, and $100 \mathrm{ml}$ of ethanol (95\%) was added to the bottle. Thenceforth, it was stirred for 2 minutes and left for 1 hour. After the powder sank, the mixture was boiled for 1 hour in the water bath, then left for 24 hours at room temperature. The mixture was filtrated and evaporated for about 1.5 hours to produce solid resin in the flask. Approximately $5 \mathrm{ml}$ of ethanol (95\%) was added to dissolve the solid resin residues in the flask wall. The solid resin was filtrated one more time using a paper filter and dried for 2 days at temperature $103 \pm 2{ }^{\circ} \mathrm{C}$. Then, the dried resin was placed in a desiccator before weighing. The resin content was measured using the following equation:

$$
\begin{aligned}
& \text { Resin Content }(\%)= \\
& \frac{\text { Dried resin - initial weight of agarwood }}{\text { Dried resin }}
\end{aligned}
$$

\section{NIR spectra acquisition}

The NIR spectra of 45 powdered samples were recorded using a spectrometer with a fibre-optic

\begin{tabular}{|c|c|c|c|c|}
\hline Type & Grade & Colour & Weight & Aroma (burned) \\
\hline \multirow{5}{*}{ Gubal } & Double super & Equally black and shiny & Sink & Soft aroma \\
\hline & Super A & Unequal black and shiny & Sink & Soft aroma \\
\hline & Super B & Black and not shiny & Float & Aromatic \\
\hline & Super middle A (under water) & Black & Float & Aromatic \\
\hline & Super middle A (up water) & Black & Float & Aromatic \\
\hline \multirow{5}{*}{ Kemedangan } & Sabah & Brownish black & Float & Aromatic \\
\hline & Kemedangan A & Brown with black line & Float & Aromatic \\
\hline & Tanggung $\mathrm{C}$ & Brown with white narrow line & Float & Aromatic \\
\hline & Kemedangan hijau & Brown with green line & Float & Aromatic \\
\hline & Kemedangan putih & Grey with black narrow line & Float & Pungent aroma \\
\hline \multirow{2}{*}{$\begin{array}{l}\text { Agarwood } \\
\text { powder }\end{array}$} & Gubal powder & Black & - & Aromatic \\
\hline & Kemedangan powder & Whitish brown & - & Quite aromatic \\
\hline
\end{tabular}
probe. The spectral range was measured between

Table 1 Agarwood grades in Indonesia (SNI 7631-2011)

Table 2 Colour criteria for determining hue value $\left({ }^{\circ} \mathrm{H}\right)$

\begin{tabular}{clc}
\hline No & Colour & ${ }^{\circ}$ H value \\
\hline 1 & Red purple & $342^{\circ}-18^{\circ}$ \\
2 & Red & $18^{\circ}-54^{\circ}$ \\
3 & Yellow red & $54^{\circ}-90^{\circ}$ \\
4 & Yellow & $90^{\circ}-126^{\circ}$ \\
5 & Yellow green & $126^{\circ}-162^{\circ}$ \\
6 & Green & $162^{\circ}-198^{\circ}$ \\
7 & Blue green & $198^{\circ}-34^{\circ}$ \\
8 & Blue & $234^{\circ}-270^{\circ}$ \\
9 & Blue purple & $270^{\circ}-306^{\circ}$ \\
10 & Purple & $306^{\circ}-342^{\circ}$ \\
\hline
\end{tabular}

Source: Winarno (1992) 
1000 to $2500 \mathrm{~nm}\left(10,000\right.$ to $\left.4000 \mathrm{~cm}^{-1}\right)$ at $4 \mathrm{~cm}^{-1}$ spectral resolution. The testing was carried out on $15 \mathrm{~g}$ of the wood meal, placed in a petri dish. A calibration device was important for the initial acquisition process. All samples were scanned with reflectance spectroscopy for approximately 30 s. Each sample was scanned three times to a total of 135 spectra and the results were averaged to produce a single spectrum. All reflectance spectra $(\mathrm{R})$, or known as original spectra, were converted to absorption spectra (A) with the following formula:

$$
\mathrm{A}(\%)=\log \frac{1}{\mathrm{R}}
$$

For data analysis, a total of 135 NIR spectra were constructed using cross-validation (CV) and test sets, or calibration and validation set. The samples were manually divided into two groups, calibration (2/3 data or 90 spectra) and validation set ( $1 / 3$ data or 45 spectra) group.

A partial least square regression (PLSR) was developed to find the best correlation function between NIR spectral data and resin content. The statistical summary generated was used to select the predictive model to estimate the resin content. The strength and accuracy of the model were expressed by the coefficient of determination $\left(R^{2}\right)$, squared error calibration (SEC), squared error prediction (SEP) and the ratio of performance to deviation (RPD). An RPD value explains the ability of a NIRS model to estimate a constituent. According to Hein (2010), RPD between 1.5 to 2.5 was sufficient for estimating wood properties, while Henri et al. (2002) stated that RPD up to 3.0 indicated the model was well for screening. For a more reliable model, the $\mathrm{R}^{2}$ value should be high, while the squared error value, both calibration and validation, should be lower. If the result of PLSR with raw spectra was not satisfying, then pre-treatment spectra were preferred to get a better model.The following pre-treatment methods were used before model building, such as Savitzky-Golay's first and second derivatives, smoothing and standard normal variate (SNV). The NIRCal 5.2 chemometric software was used for spectral processing and data analysis. The pre-treated spectra were analysed similar as raw spectra using PLS regression (PLSR). The result of PLSR was selected to get the best model with good reliability.

\section{RESULTS AND DISCUSSION}

\section{Quality of agarwood}

According to SNI 7631-2011, the samples were tested based on colour, weight and aroma, which were categorised into grades of kemendangan A to gubal gaharu (super middle A). The sample characteristics consisted of brown with a black line to black, float to afloat, and aromatic, all belonging to kemendangan $\mathrm{A}$ and gubal gaharu (super middle A). Previous research by Waluyo and Anwar (2012) stated that marketed agarwood in Indonesia was dominated by grade kemendangan $\mathrm{A}$, kemendangan $\mathrm{B}$, kacangan $\mathrm{A}$ and teri $\mathrm{B}$. The grade of kacangan $\mathrm{A}$ and teri $\mathrm{B}$ was the grade of a local trade name with lower quality that was not listed in SNI 7631-2011.

\section{Colour determination}

Colour determination using chromameter showed that $\mathrm{L}^{*}, \mathrm{~b}^{*}$ and ${ }^{\circ} \mathrm{H}$ of kemendangan were higher than gubal gaharu. Meanwhile, $\mathrm{a}^{*}$ and $\mathrm{C}^{*}$ of kemendangan was lower (Figure 2 ). Figure 3 and 4 show the results of colour determination; the ${ }^{\circ} \mathrm{H}$ value of gubal gaharu and kemendangan were 73.13 and 75.07 , respectively. Table 2 shows that ${ }^{\circ} \mathrm{H}$ values of both gubal gaharu and kemendangan, fall into yellow red colour because the values were in the range of $54-90^{\circ}$. The colour of kemendangan tended to be brighter than gubal due to higher ${ }^{\circ} \mathrm{H}$ value. These quantification values were in line with grade characteristics as revealed by Indonesian's standard for agarwood chips and powder (Table 1).

\section{Resin content}

The resin content of gubal gaharu ranged from 12.04 to $40.31 \%$ with a mean and standard

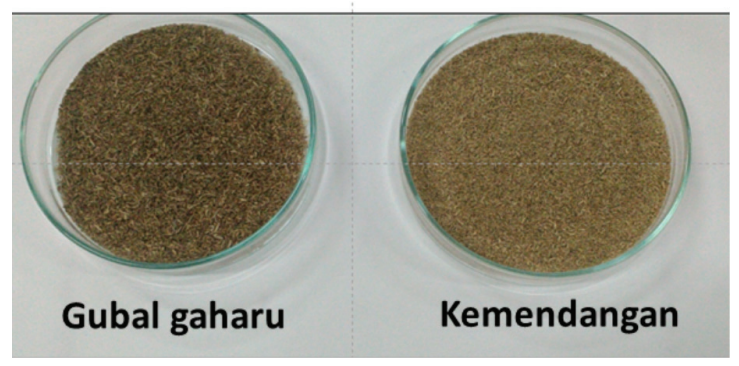

Figure 2 Agarwood powder of gubal gaharu and kemendangan 


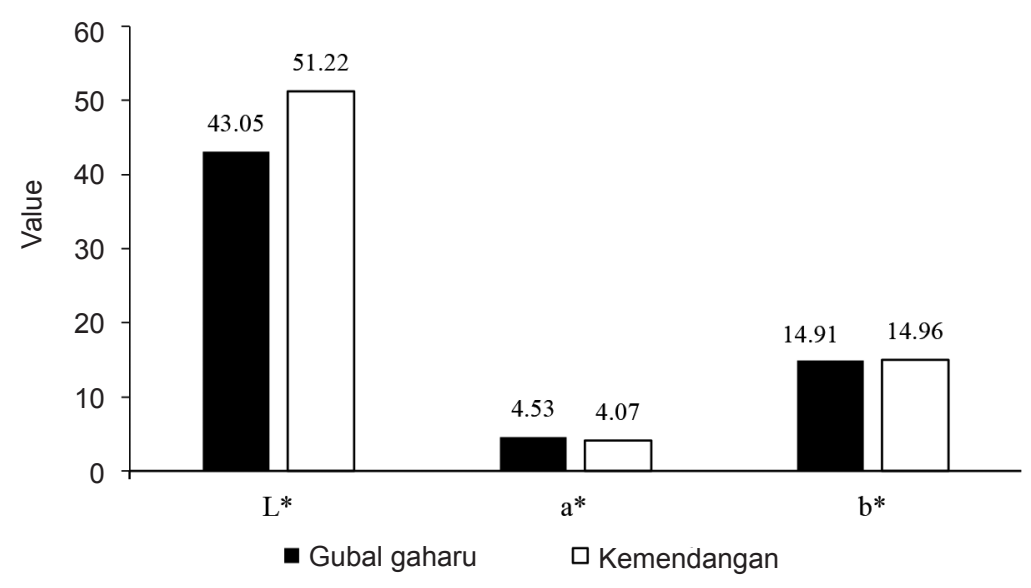

Figure 3 Level of lightness $\left(\mathrm{L}^{*}\right)$, yellowness $\left(\mathrm{b}^{*}\right)$ and redness $\left(\mathrm{a}^{*}\right)$

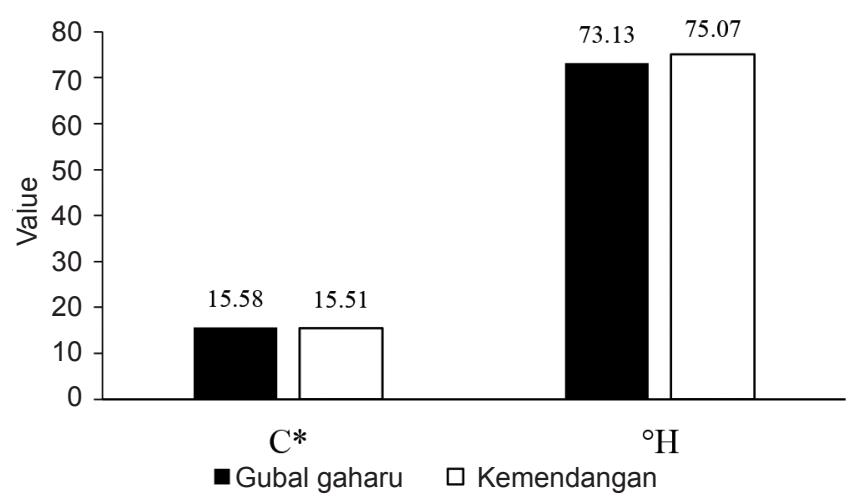

Figure 4 Degrees of chroma $\left(\mathrm{C}^{*}\right)$ and hue value $\left({ }^{\circ} \mathrm{H}\right)$

deviation (SD) of $24.74 \%$ and $11.05 \%$, respectively. Meanwhile, kemendangan had lower resin content between 6.33 to $20.44 \%$ with a mean and SD of $12.22 \%$ and $3.13 \%$. Gubal gaharu had resin contents twice that of kemendangan. The results corresponded with colour determination; the higher the resin content, the lower the $\mathrm{L}^{*}$ value. In other words, the darker the colour, the higher the resin content. Previous research stated that agarwood with grades of kemendangan A and B from Samarinda, East Kalimantan had resin content of 17.76 and $23.42 \%$ (Waluyo \& Anwar 2012). Difference in resin content depends on the diversity of species and geographical origin or growth site.

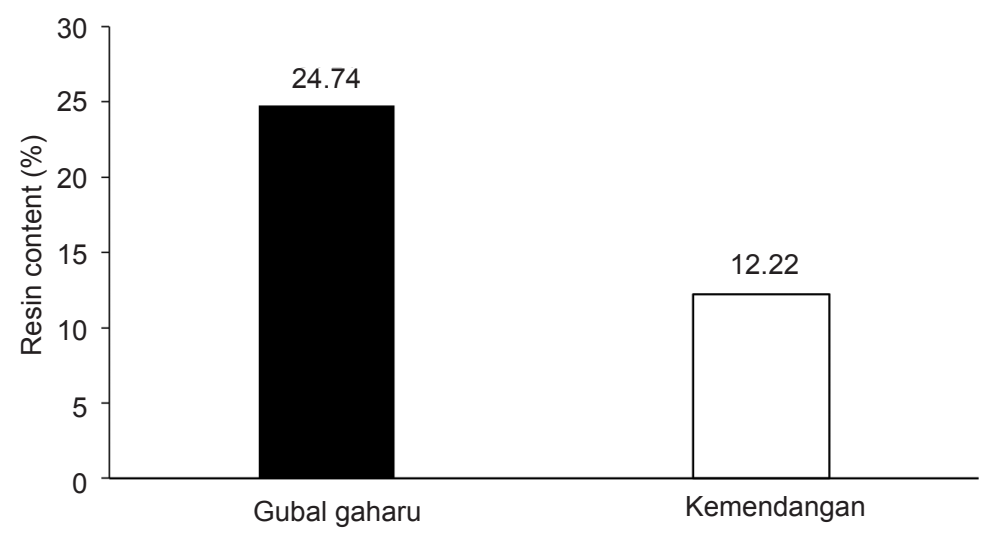

Figure 5 Resin content of agarwood 
Table 3 shows that gubal gaharu is classified as grade $\mathrm{B}$ to $\mathrm{A}$, whereas kemendangan as grade C. Azah et al. (2013) stated that some of the agarwood products from Indonesia had a resin content range of 6.01 to $16.24 \%$, classified as grade $\mathrm{C}$ and $\mathrm{D}$. The higher the resin yield, the higher the quality of agarwood (Pasaribu et al. 2015). Agarwood's resin is dominated by a group of sesquiterpene and cromon, which tends to influence the quality of the wood. However, there is no consistency in the types of sesquiterpene compounds in agarwood (Waluyo \& Anwar 2012). Pasaribu et al. (2015) explained that aromadendrene is one of the sesquiterpene derivatives, which is the distinguisher compound (chemical marker) of agarwood. Increasing aromadendrene chemical content indicates the increase of agarwood level. Another method to grade agarwood was through burning. Agarwood with high quality can exude more resin bubbles while burning because it contains more resin (Liu et al. 2017). Moreover, to identify the volatile compounds, essential oil can be used to discriminate sesquiterpenoid, sesquiterpenes and monoterpenes, using gas chromatography mass spectrometry (GCMS) laboratory testing for Aquliaria spp. (Tajudin et al. 2013, 2016, MohdSyafik et al. 2020).

Table 3 Classification of agarwood based on resin content

\begin{tabular}{cc}
\hline Grade & Resin Content \\
\hline A & $>30 \%$ \\
B & $20-29.99 \%$ \\
C & $9-19.99 \%$ \\
D & $<9 \%$ \\
\hline
\end{tabular}

Source: Azah et al. (2013)

\section{Spectroscopy analysis}

The basic fundamental of NIRS acquisition was that NIR sent infrared radiation of about 1000 to $2500 \mathrm{~nm}$ to the samples, which radiation transmittance affected the reflection and absorption. Figure 6 shows that gubal gaharu had higher absorbance with a range of 0.1373 to 0.5277 than of kemendangan $(0.1313$ to $0.4913)$. The absorbance continued to increase to wavelengths of $2500 \mathrm{~nm}$ due to changes in wood tissue due to infections, resulting in the release of resinous compounds (Faizal et al. 2017).
Figure 6 also shows a distinct peak of absorbance due to molecules' vibration. The NIR spectra detects organic and inorganic compounds, which causes a distinct absorbance for each material (Karlinasari et al. 2014). The presence of aromatic compounds was indicated with vibrational $\mathrm{C}-\mathrm{H}$ bonds around 1143, 1417, 1446 and $1685 \mathrm{~nm}$ (Osborne et al. 1993). Workman \& Weyer (2007) stated that the presence of resin was indicated by wavelength $2220 \mathrm{~nm}$, caused by the vibration of $\mathrm{CH}+\mathrm{CO}$ bonds in the resin. A study by Karlinasari et al. (2021) on ebony wood revealed that at bands of $1900 \mathrm{~nm}, 2260 \mathrm{~nm}$ and $2440 \mathrm{~nm}$ had significant extractive contents. Adi et al. (2020) reported that the cellulose, lignin and extractive were in a range of 4890 to $4620 \mathrm{~cm}^{-1}$ or about (2083 to 2100 $\mathrm{nm})$ spectra wavelength. The PLS-DA has been succeessful in discriminating the normal and infected agarwood. The present study found that the resin content of agarwood could be detected at wavelength peak of $1930 \mathrm{~nm}$, with absorbance value of 0.414 and 0.3667 for gubal gaharu and kemendangan, respectively. There was significant spectral difference between gubal gaharu and kemendangan. The NIR spectrum consisted of many bands due to overtone and combination modes that usually overlap (Schwanninger et al. 2011). If there were only overtone bands in the NIR, the interpretation of spectra would be easier. However, the region also contained groups of combination bands with lower intensity.

The quality of the prediction model of wood properties depended on $\mathrm{R}^{2}$ and RPD, as well as square error (SE) values. Data pre-treatment and primary components (PC) determination were done to avoid a high bias. Determining the PC is a vital component in building a calibration model, that influences the accuracy obtained. If the PC were overused, the model would be overfitting, and if underused, there would be more excision of data (Kelley et al. 2004). Table 4 shows that the first and second derivatives were the best pretreatments for the regression model developed, because the combination of $\mathrm{R}^{2}$ calibration and validation, and the RPD values were the highest. The equation model of calibration and validation showed that the $\mathrm{R}^{2}$ were 0.712 and 0.463 , respectively (Table 4 and Figure 7), meanwhile, the SE calibration and validation were 3.877 and 4.196, respectively. The RPD value was 1.45 , indicating that the model was quite satisfactory for predicting wood properties. The results were complemented by a previous study by Adi et al. 


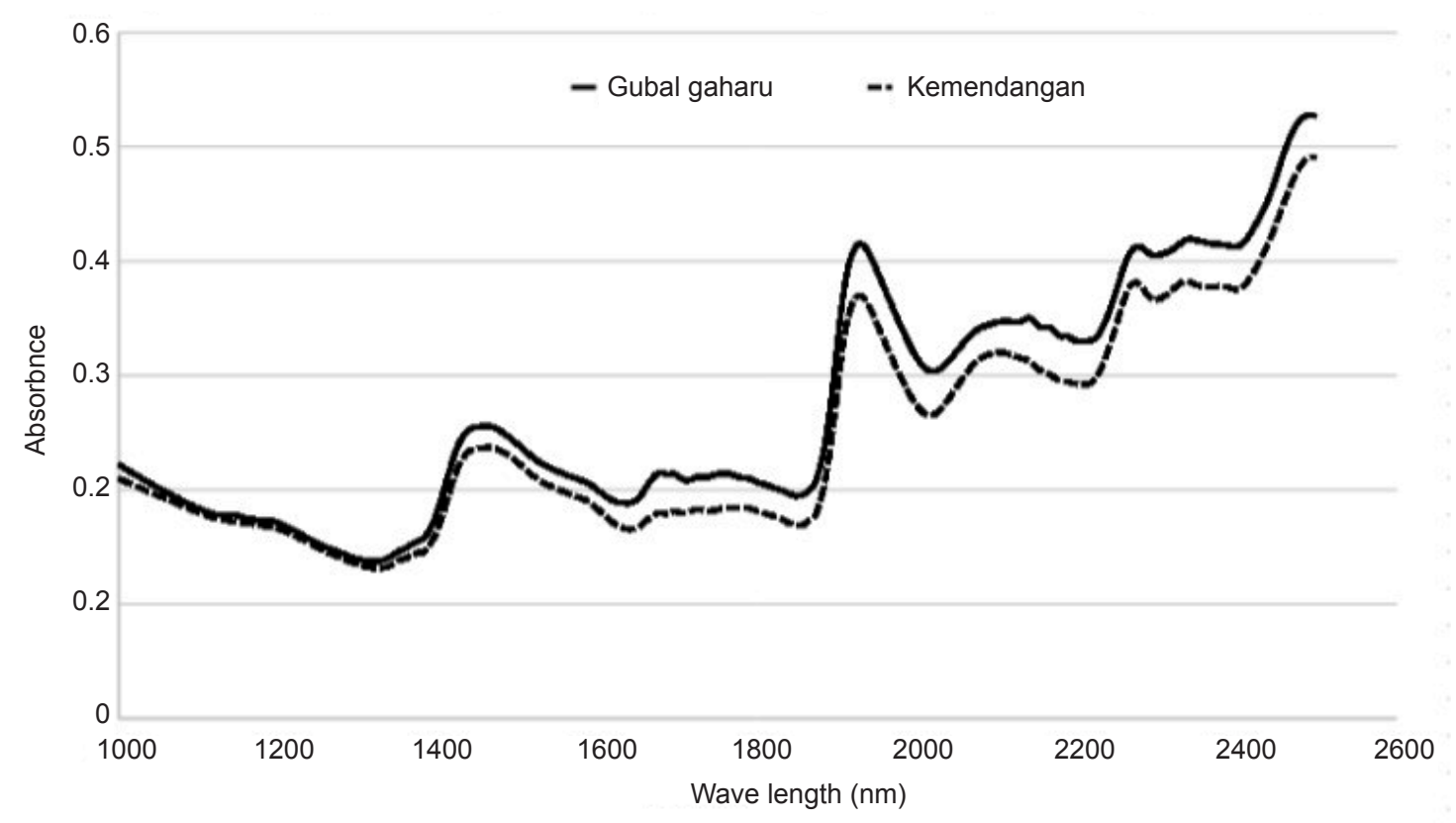

Figure 6 Original NIR spectra of agarwood based on grade

Table 4 Results of PLS regression on spectra and resin content of agarwood

\begin{tabular}{lcccccc}
\hline \multirow{2}{*}{ Pre-treatment } & & \multicolumn{2}{c}{ Calibration } & \multicolumn{2}{c}{ Validation } & \multirow{2}{*}{ RPD } \\
\cline { 3 - 5 } & PC & $\mathrm{R}^{2}$ & $\mathrm{SEC}$ & $\mathrm{R}^{2}$ & $\mathrm{SEP}$ & \\
\hline Raw Spectra & 2 & 0.2862 & 6.1065 & 0.3515 & 3.3961 & \multirow{2}{*}{1.13} \\
Smoothing & 2 & 0.2862 & 6.1066 & 0.3515 & 3.3962 & 1.13 \\
$1^{\text {st }} \& 2^{\text {nd }}$ derivative & 2 & 0.7122 & 3.8778 & 0.4634 & 4.1960 & 1.45 \\
SNV & 2 & 0.4057 & 5.5720 & 0.5692 & 2.9465 & 1.56 \\
\hline
\end{tabular}

$\mathrm{PC}=$ primary components, $\mathrm{R}^{2}=$ coefficient determination, $\mathrm{SEC}=$ squared error calibration, $\mathrm{SEP}$ = squared error prediction, $\mathrm{RPD}=$ ratio prediction to deviation, $\mathrm{SNV}=$ standard normal variate

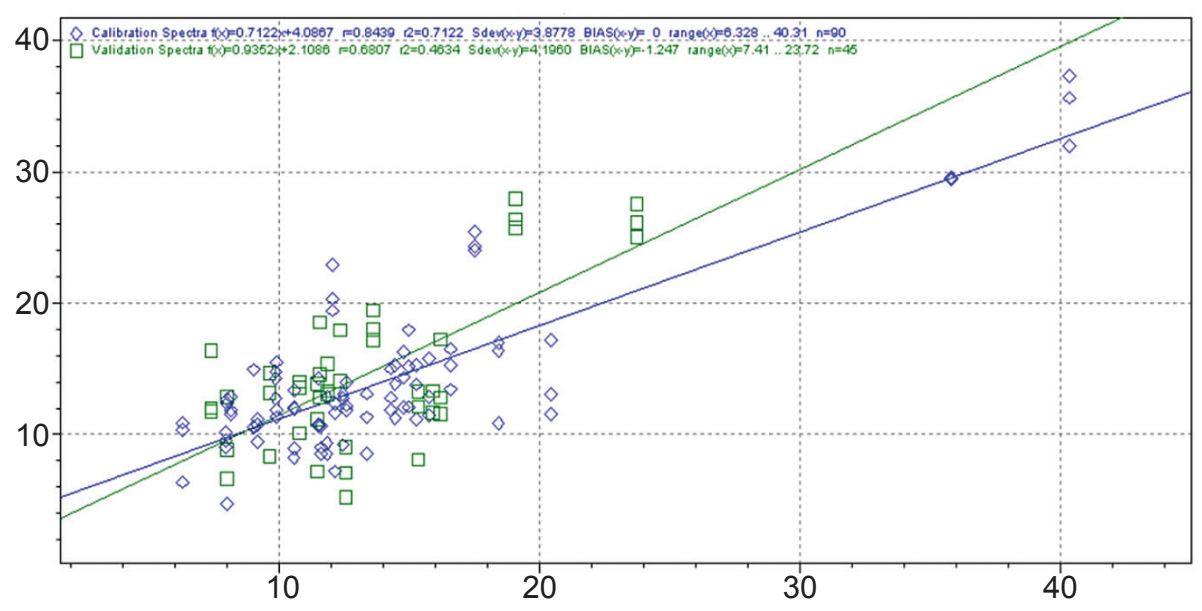

Figure 7 Equation on regression model of agarwood 
(2020) who discriminated normal and infected agarwood. Predicting agarwood quality based on their extractive content using NIRS can be potentially used as a fast predictive and reliable tool.

\section{CONCLUSION}

The agarwood obtained from Bintan island were in the quality grade of gubal gaharu (super middle A) and kemendangan $\mathrm{A}$, or in grade B to A, and grade $\mathrm{C}$, respectively, based on appearances and physical characteristics referred by Indonesian standard. The colour of gubal gaharu was darker than kemendangan because it has higher resin content. The results showed that the higher the resin content, the darker the colour. Resin of agarwood was detected at NIRS wavelength of around $2000 \mathrm{~nm}$. A PLSR model using NIRS, to predict agarwood quality based on resin content with good accuracy, was successfully developed. This method can be potentially used as a fast and reliable tool.

\section{ACKNOWLWDGEMENT}

The authors would like to thank the Ministry of Research, Technology and Higher Education for the research grant.

\section{REFERENCES}

BSN (BADAN Standarisasi NASIONAL). 2011. SNI-7631: Gaharu. Badan Standardisasi Nasional Indonesia, Jakarta.

Adi DS, Hwang SW, Pramasari DA et al. 2020. Spectral observation of agarwood by infrared spectroscopy: the differences of infected and normal Aquilaria microcarpa. Biodiversitas 21: 2893-2899.

Azah M, Saidatul HS, Mailina J, Sahrim L, Abdul Mj \& Mohd FZ. 2013. Classification of agarwood (gaharu) by resin content. Journal of Tropical Forest Science 25: 213-219.

Faizal A, Esyanti RR, Aulianisa EN, Iriawati, Santoso E \& Turjaman M. 2017. Formation of agarwood from Aquilaria malaccensis in response to inoculation of local strains of Fusarium solani. Trees 31: 189-197.

Giovannucci D \& Reardon T. 2000. Understanding Grades and Standards and How To Apply Them. Federal Reserve Bank of St Louis, St. Louis.

He W \& Hu H. 2013. Prediction of hot-water-soluble extractive, pentosan and cellulose content of various wood species using FT-NIR spectroscopy. Bioresources Technology 140: 299-305.

Hein PRG. 2010. Multivariate regression methods for estimating basic density in Eucalyptus wood from nearinfrared spectroscopic data. Suplemento 16: 90-96.

Henri B, Fabrice D \& Frédérique HP. 2002. Near-infrared analysis as a tool for rapid screening of some major wood characteristics in a eucalyptus breeding program. Annals of Forest Science 59: 479-490.

Jiang W, Han G, Via BK, Tu M, Liu W \& Fasina O. 2013. Rapid assessment of coniferous biomass lignincarbohydrates with near-infrared spectroscopy. Wood Science Technology 48: 109-122.

ITo N, Окubo N \& Kurata Y. 2019. Nondestructive nearinfrared spectroscopic analysis of oils on wood surfaces. Forests 10: 1-7.

Karlinasari L, Sabed M, Wistara INJ \& Purwanto YA. 2014. Near-infrared (NIR) spectroscopy for estimating the chemical composition of Acacia mangium Willd. wood. Journal of the Indian Academy of Wood Science 11: 162-167.

Karlinasari L, Noviyanti, Purwanto YA et al. 2021. Discrimination and determination of extractive content of ebony (Diospyros celebica Bakh.) from Celebes island by near-infrared spectroscopy. Forests 12: 1-11.

Kelley SS, Rials TG, Snell R, Groom LH \& Sluiter A. 2004. Use of near-infrared spectroscopy to measure the chemical and mechanical properties of solid wood. Wood Science Technology 38: 257-276.

Liu YY, Wei JH, GaO ZH, Zhang Z \& LyU JC. 2017. A review of quality assessment and grading for agarwood. Chinese Herbal Medicine 9: 22-30.

López-SAmpson A \& Page T. 2018. History of use and trade of agarwood. Economy Botany 20: 1-23.

Mohamed R \& Lee SY. 2016. Keeping up appearances: Agarwood grades and quality. Pp 149-167 in Mohamed R (ed) Agarwood: Science Behind The Fragrance. Springer, Singapore. DOI: 10.1007/978981-10-0833-7_10.

Mohd-Syafik, Che-Mohd-Aizal CM, Siti-Hajar NS, Lee SY, Mohamed R \& Syaiful NT. 2020. Characterisation of Aquilaria hirta based on morphology evaluation and volatile chemical compound. Journal of Tropical Forest Science 32: 289-295. https://doi.org/10.26525/ jtfs2020.32.3.289.

Osborne BG, Fearn T \& Hindle PH. 1993. Practical NIR Spectroscopy with Application in food and Beverage Analysis. Longman Scientific \& Technical, Harlow.

Pasaribu G, Waluyo, TK \& PARI G. 2015. Analysis of chemical compounds distinguisher for agarwood qualities. Indonesian Journal Forest Resources 2: 1-7.

Popescu CM, Navi P, Placencia Peña MI \& Popescu MC. 2018. Structural changes of wood during hydro-thermal and thermal treatments evaluated through NIR spectroscopy and principal component analysis. Spectrochimica Acta A 191: 405-412.

Schwanninger M, Rodrigues JC \& Fackler K. 2011. A review of band assignments in near-infrared spectra of wood and wood components. Journal of Near Infrared Spectroscopy. 19: 287-308.

Tajuddin SN, Muhamad NS, Yarmo MA \& Yusoff MM. 2013. Characterization of the chemical constituents of agarwood oils from Malaysia by comprehensive twodimensional gas chromatography-time-of-flight mass spectrometry. Mandeleev Communications 23: 51-52.

Tajuddin SN, Yusoff MM \& Aizal CM. 2016. Resolution of complex sesquiterpene hydrocarbons in Aquilaria malaccensis volatile oils using gas chromatography 
technique. Pp 103-124 in Mohamed R (ed) Agarwood: Science Behind The Fragrance. Springer, Singapore.

Traoré M, Kaal J \& Martínez CA. 2018. Differentiation between pinewoods according to species and growing location using FTIR-ATR. Wood Science and Technology 52: 487-504.

Tsuchikawa S \& Kobori H. 2015. A review of recent application of near-infrared spectroscopy to wood science and technology. Journal of Wood Science 61: 213-220.
Waluyo TK \& Anwar F. 2012. Chemical component identification of four agarwood grades: Kacangan A, Teri B, Kemendangan A and Kemendangan B. Jurnal Penelitian Hasil Hutan 30: 291-300.

WHO (World Health Organization). 1998. Quality Control Methods for Herbal Materials : Determining of Extractable Matter. World Health Organization, Geneva.

Winarno FG. Kimia Pangan dan Gizi. Gramedia Pustaka Utama, Jakarta.

WORKMAN JJ \& WEYER L. 2007. Practical Guide to Interpretive NearInfrared Spectroscopy. CRC Press, New Yorks. 